\title{
ISOLATION AND CHARACTERIZATION OF ARSENIC RESISTANT SOIL BACTERIA AND THEIR EFFECTS ON GERMINATION OF RICE UNDER ARSENIC CONTAMINATION
}

\author{
Istiaq Ahmed ${ }^{1 \star}$, Md. Tofazzal Islam ${ }^{2}$, Md. Akhter Hossain Chowdhury ${ }^{1}$ and \\ Md. Kamruzzaman ${ }^{3}$
}

'Department of Agricultural Chemistry, Faculty of Agriculture, Bangladesh Agricultural University, Mymensingh-2202, Bangladesh; ${ }^{2}$ Department of Biotechnology, Bangabandhu Sheikh Mujibur Rahman Agricultural University, Salna, Gazipur, Bangladesh; ${ }^{3}$ Plant Breeding Division, Bangladesh Institute of Nuclear Agriculture (BINA), Mymensingh-2202. Bangladesh

*Corresponding author: Istiaq Ahmed, E-mail: istiaq@bau.edu.bd

\section{ARTICLE INFO}

\section{Received}

06.08.2015

Accepted

28.08.2015

Online

03.09.2015

Key words

Arsenic

Rice

Bacteria

Resistant

Germination

Growth

\section{ABSTRACT}

This study was carried out to isolate, screen and characterize arsenic (As) resistant bacteria from As contaminated soils of Dumrakandi and Matlab under Faridpur and Chandpur districts and to evaluate their efficiency in reducing As toxicity against rice seedlings during germination. Thirteen strains were isolated from the soils which showed resistance to different levels of sodium arsenite ( viz. 5, 10, 20 and $40 \mathrm{mM}$ ) in both agar plate and broth assay using BSMY I media. Among the isolates, BTL0011, BTL0012, BTL0015 and BTL0022 showed highest resistance to $40 \mathrm{mM}$ sodium arsenite. Gram staining and $\mathrm{KOH}$ solubility test revealed that five strains were gram positive and rest eight was gram negative. They grew well in the liquid media at pH 5.5 to 8.5. In-vitro rice seedling bioassay with two superior isolates (BTL0011 and BTL0022) revealed that As resistant strains significantly enhanced seed germination of BRRI dhan29 and BRRI dhan47 at 60 ppm As. This study was laid out in CRD with three replications. The performance of BTL 0022 was superior to BTL0011. The overall results suggest that BTL0011 and BTL0022 can be used for bioremediation of As contaminated soils and to increase the germination and seedling growth of rice in As contaminated soils.

To cite this article: I Ahmed, MT Islam, MAH Chowdhury and M Kamruzzaman, 2015. Isolation and characterization of arsenic resistant soil bacteria and their effects on germination of rice under arsenic contamination. Res. Agric. Livest. Fish. 2 (2): 229-237.

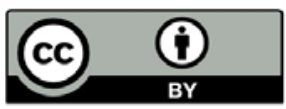

This is an open access article licensed under the terms of the Creative Commons Attribution 4.0 International License

www.agroaid-bd.org/ralf, E-mail: editor.ralf@gmail.com 


\section{INTRODUCTION}

Arsenic (As), which have carcinogenic, mutagenic and teratogenic properties is a major constituent in more than 245 minerals and is ubiquitous in the environment (Mandal and Suzuki, 2002). It is found responsible for bladder, kidney, liver, lung, and skin cancers and is listed as a class A human carcinogen by the USEPA (Chen et al., 2002). Both acute and chronic poisoning to human has raised great concerns, especially in heavily contaminated areas such as Bangladesh and West Bengal, India.

Arsenic is a semi-metallic element, which may be found in a variety of forms, viz. $-3,0,+3,+5$ valencies. Numerous environmental factors influence As speciation in soil, such as $\mathrm{pH}$, redox potential, the presence of other ions, organic matter content, soil texture, fungal or bacterial activities (Turpinen et al., 1999). Several remediation techniques for As removal have been applied, viz. ion exchange, adsorption with activated alumina and activated carbon, ultrafiltration, reverse osmosis, and complexation with metal ions followed by coagulation. These physic-chemical treatment methods require large amount of chemical reagents that are expensive and may result secondary environmental pollution. Due to these apparent disadvantages of the above physico-chemical treatments, novel techniques for the reduction of contaminant toxicity with minimizing cost have been proposed. Biological remediation techniques, either using living/dead cells or biosynthesized molecules have been examined (Katsoyiannis et al., 2002). Studies have shown that microorganisms are able to accumulate metal ions via processes such as transportation across the cell membrane, biosorption onto cell wall, entrapment in extracellular capsule, precipitation, oxidation-reduction reaction and biosorption to extracellular polysaccharide (Malik, 2004). Bacteria have developed a variety of mechanisms to avoid the toxicity of As including (a) minimizing the uptake of $A s(V)$ through the system for phosphate uptake; (b) by peroxidation reactions with membrane lipids and (c) using the best characterized microbial As detoxification pathway involving the ars operon (Holt, 1994). Therefore, this study was designed to isolate and screen As resistant bacteria from the As contaminated soil and to examine effects of As resistant bacteria on seed germination and seedling growth of rice under arsenic contaminations.

\section{MATERIALS AND METHODS}

\section{Soil sample collection and bacteria isolation}

Arsenic contaminated soils were collected from the two locations of Faridpur near Dumrakandi and Chandpur near Nagda Bazar, Matlab under AEZ 12 and 17, respectively, of Bangladesh. Surface soil (0 to 15 $\mathrm{cm}$ depth) were collected, placed in plastic bag and kept at $4^{\circ} \mathrm{C}$ until further analysis. Some physio-chemical parameters of soil like $\mathrm{pH}$, arsenic content $\left(\mu \mathrm{g} \mathrm{g}^{-1}\right)$, available $\mathrm{P}\left(\mu \mathrm{g} \mathrm{g}^{-1}\right)$, available $\mathrm{S}\left(\mu \mathrm{g} \mathrm{g}^{-1}\right)$, exchangeable $\mathrm{K}$ (meq/100 g soil) were measured. The BSMY I medium (Yamamura et al., 2003) was used for the isolation of bacteria from As contaminated soil samples contained the following ingredients $\left(\mathrm{g} \mathrm{L}^{-1}\right): 1 \mathrm{~g}$ yeast extract, $0.3 \mathrm{~g}$ $\left(\mathrm{NH}_{4}\right)_{2} \mathrm{SO}_{4}, 0.14 \mathrm{~g} \mathrm{MgSO}_{4} .7 \mathrm{H}_{2} \mathrm{O}, 0.2 \mathrm{~g} \mathrm{CaCl} 2.2 \mathrm{H}_{2} \mathrm{O}, 0.1 \mathrm{~g} \mathrm{NaCl}, 0.05 \mathrm{~g} \mathrm{KH}_{2} \mathrm{PO}_{4}, 0.05 \mathrm{~g} \mathrm{~K} \mathrm{HPO}_{4}, 0.0006 \mathrm{~g}$ $\mathrm{H}_{3} \mathrm{BO}_{3}, 0.00017 \mathrm{~g} \mathrm{CoCl}_{2} .6 \mathrm{H}_{2} \mathrm{O}, 0.00009 \mathrm{~g} \mathrm{CuCl}_{2} .2 \mathrm{H}_{2} \mathrm{O}, 0.0001 \mathrm{~g} \mathrm{MnCl}_{2} .4 \mathrm{H}_{2} \mathrm{O}, 0.00022 \mathrm{~g} \mathrm{ZnCl}, 10 \mathrm{~g}$ glucose. The ingredients were dissolved in Tris- $\mathrm{HCl}$ buffer and $\mathrm{pH}$ of the medium was adjusted at 8.0 before autoclaving the medium. The BSMY II medium (Kuai et al., 2001) was prepared to study growth phase of bacteria using the following ingredients $\left(\mathrm{g} \mathrm{L}^{-1}\right): 1 \mathrm{~g}$ yeast extract, $0.25 \mathrm{~g} \mathrm{NH}_{4} \mathrm{Cl}, 0.62 \mathrm{~g} \mathrm{MgCl}_{2} .6 \mathrm{H}_{2} \mathrm{O}, 0.15 \mathrm{~g}$ $\mathrm{CaCl}_{2} .2 \mathrm{H}_{2} \mathrm{O}, 0.1 \mathrm{~g} \mathrm{NaCl}, 0.14 \mathrm{~g} \mathrm{KH}_{2} \mathrm{PO}_{4}, 0.5 \mathrm{~g} \mathrm{KCl}, 0.00006 \mathrm{~g} \mathrm{H}_{3} \mathrm{BO}_{3}, 0.00012 \mathrm{~g} \mathrm{CoCl}_{2} .6 \mathrm{H}_{2} \mathrm{O}, 0.000015 \mathrm{~g}$ $\mathrm{CuCl}_{2} .2 \mathrm{H}_{2} \mathrm{O}, 0.0001 \mathrm{~g} \mathrm{MnCl}_{2} .4 \mathrm{H}_{2} \mathrm{O}, 0.00022 \mathrm{~g} \mathrm{ZnCl}_{2}, 10 \mathrm{~g}$ glucose. The ingredients were dissolved in deionized water adjusted to $\mathrm{pH} 6.8$ with $\mathrm{NaHCO}_{3}$. Two grams of each soil sample was dissolved in $20 \mathrm{~mL}$ $0.9 \% \mathrm{NaCl}$ and shaken for 3 minutes. Then $5 \mathrm{~mL}$ of soil suspension was inoculated into $50 \mathrm{~mL}$ BSMY I containing $5 \mathrm{mM}$ sodium-arsenite and incubated at $25^{\circ} \mathrm{C}$ on rotary shaker at $120 \mathrm{rpm}$ for 3 days for isolation of As resistant bacteria. Five $\mathrm{mL}$ of culture was transferred into fresh BSMY I medium containing $10 \mathrm{mM}$ sodiumarsenite, and transferred twice into new medium that was supplemented with 20 and $40 \mathrm{mM}$ sodium-arsenite. After growth was observed, $0.1 \mathrm{ml}$ of culture was spreaded on BSMY II agar that contained $40 \mathrm{mM}$ sodiumarsenite and incubated at $25^{\circ} \mathrm{C}$ for 3 days. Bacterial isolates that could tolerate the highest As concentration were selected and identified by their morphological features and biochemical properties. Individual colonies of isolated strains of BTLs were picked from BSYM II agar medium and streaked on NBA medium for their mass growth. The culture of each isolate was stored in the $20 \%$ glycerol at $-20^{\circ} \mathrm{C}$ for further studies. 


\section{Biochemical characterization of bacterial strains}

\section{Gram staining reaction}

Bacterial cultures (after 24 hours incubation) for each isolate were taken to perform the gram reaction test. Bacterial mass were taken out from culture, spread on clean glass slide followed by drying in air without heat and was flamed it lightly and gently to settle the bacteria. Crystal violet was then poured over the bacterial smear on the slide for 2-3 minutes and washed in tap water for 1 minute and lightly blot dry on a paper towel to remove crystal violet. The smear was flooded with iodine solution for 1 minute and washed in tap water for few seconds and then blot dried. It was decolorized with solvent e.g. alcohol, until the solvent flowed colorlessly from the slide (about 2-4 seconds) and rinse in tap water for 5 seconds. Then the smear was counterstained for about 1 minute with safranin solution and washed briefly in tap water followed by blot dry. One drop emulsion oil was then added on the slide and placed it on compound microscope with 100x magnification for observation.

\section{Potassium hydroxide solubility test}

A loopful of bacteria was picked from a well grown colony with a sterilized toothpick and mixed with a drop of $3 \%$ aqueous potassium hydroxide solution on a glass slide for less than 10 seconds. After mixing, the toothpick was raised a few centimeters from the glass slide. Strands of viscid material confirmed the bacterium was gram-negative.

\section{Growth of the bacterial isolates at varying $\mathrm{pH}$}

The arsenic resistant bacteria isolates were grown in BSMY II broth cultures with varying levels of $\mathrm{pH}$ (5.5 to 8.5) in a incubator shaker up to 48 hours at $25^{\circ} \mathrm{C}$ to see their growth. The optical density of the broth culture was recorded by a spectrophotometer (PD-3003 UV, APEL) at $600 \mathrm{~nm}$ to measure the growth of the bacterial strains. Each treatment was replicated three times and data were expressed as the mean value.

\section{Effects of bacterial inoculation on germination and seedling growth of rice}

The test tubes for this in-vitro culture of the rice seedlings were washed with detergents and rinsed with deionized water and then autoclaved for the sterilization. Two strains of arsenic resistant bacteria (resistant to $40 \mathrm{mM} \mathrm{NaAsO}$ ) were selected from the previously isolated arsenic resistant bacterial strains and designated by BTL0011 and BTL0022, respectively. They were cultured in BSMY I broth medium for 3 days at $25 \pm 1^{\circ} \mathrm{C}$ temperatures in a shaker at $120 \mathrm{rpm}$. When growth was found optimum; the cultures were checked for purity and population. Then these were centrifuged at $5500 \mathrm{rpm}$ repeatedly with deionized distilled water for three times. Then these bacterial cells without any culture media were suspended in sterilized water. These bacterial suspensions were used for seed inoculation of rice for in-vitro culture. The selected varieties of rice were BRRI dhan29 and BRRI dhan47. Seeds were surface sterilized by using $70 \%$ ethanol for 10 minutes, $1 \%$ $\mathrm{NaOCl}$ for 1 minute and $100 \%$ ethanol for five minutes, respectively after every step washed by distilled water for five times. The seeds were then soaked in the bacterial suspension for 12 hours. After that, these seeds coated with bacteria were kept in blotting paper for absorbing extra aqueous mass from the seeds. These seeds were then used for in-vitro culture. The bacteria coated seeds were placed on agar media taken into test tubes $(18 \times 1.6 \mathrm{~cm})$ for in-vitro culture. The conducted experiment was a three factor experiment viz. rice varieties, arsenic resistant bacterial inoculants and different concentration level of As. The agar-water containing no arsenic and no arsenic resistant bacteria was used as control. Different concentration levels of As were $5 \mathrm{ppm}, 30 \mathrm{ppm}, 45 \mathrm{ppm}$ and $60 \mathrm{ppm}$. The plant height (shoot and root length of seedlings) were measured 7 days after seed sowing. The in vitro experiment was laid out in CRD (Completely Randomized Design) with 3 replications.

\section{Statistical analysis}

The statistical analysis of the experiment was carried out using statistical computer package MSTAT-C. The ANOVA followed by Duncan's Multiple Range Test (DMRT) were to be analyzed for the present study (Gomez and Gomez, 1984). 


\section{RESULTS AND DISCUSSION}

\section{Physio-chemical characteristics of bacterial isolates}

The $\mathrm{pH}$ of the soil samples ranged from 5.79 to 8.01 , soil arsenic ranged from $35.50 \pm$ $37.14 \pm 0.02 \mathrm{ug} \mathrm{g}^{-1}$ in Faridpur soil and $5.79 \pm 0.03$ to $6.29 \pm 0.02$ in chandpur soil, available $P$ ranged from $1.19 \pm 0.01$ to $4.33 \pm 0.04 \mu \mathrm{g} \mathrm{g}^{-1}$, available $S$ ranged from $57.16 \pm 0.03$ to $316.59 \pm 0.04 \mu \mathrm{g} \mathrm{g}^{-1}$, and exchangeable $\mathrm{K}$ (meq/100 g soil) ranged from $0.12 \pm 0.01$ to $0.35 \pm 0.03$.

\section{Isolation of arsenic resistant bacteria from the contaminated soils}

Thirteen bacterial strains were isolated at different sodium-arsenite concentrations. This result suggests that the isolates might have developed As resistance to protect sensitive cellular components. It was observed that most isolates (BTL0014, BTL0015, BTL0017, BTL0019, BTL0020, BTL0021, BTL0022 and BTL0023) had an off-white colour. Some isolates (BTL0011, BTL0012, BTL0013 and BTL0018) also had pale yellow and deep yellow (BTL0016) colour (Fig. 1).
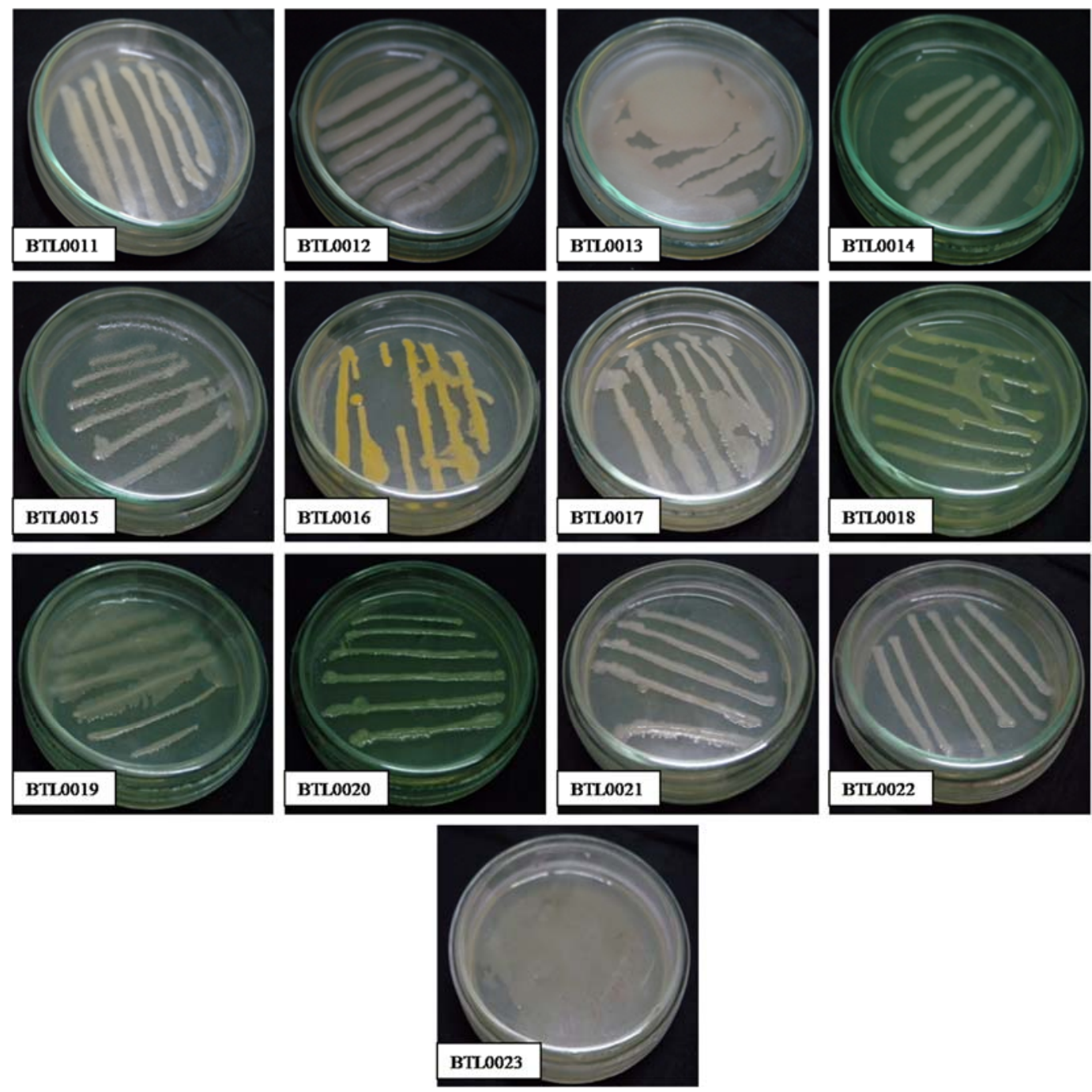

Figure 1. Arsenic resistant bacteria grown in $5 \mathrm{mM}$ sodium arsenite 
In general, microbial ability to grow at high As concentration was found coupled with a variety of specific mechanisms of resistance and environmental factors. It include microbial surface sorption, enzymatic transformation, precipitation by oxidation/reduction reaction and biosynthesis of metal binding proteins or extracellular polymers, whereas environmental factors may include the surrounding $\mathrm{pH}$ and redox potential, metal speciation, soil particulates and soluble organic matters (Srinath et al., 2002; Zouboulis et al., 2004).

\section{Effect of arsenic on bacterial growth}

Bacterial growth was retarded at different concentrations of sodium arsenite. Four strains (BTL0011, BTL0012, BTL0015 and BTL0022) showed exponential growth at $40 \mathrm{mM}$ sodium arsenite. Whereas six strains (BTL0014, BTL0016, BTL0018, BTL0019, BTL0020 and BTL0021) were grown up to $20 \mathrm{mM}$ sodium arsenite. The strain BTL0013 was grown up to $10 \mathrm{mM}$ sodium arsenite. Two strains (BTL0017 and BTL0023) were grown only at $5 \mathrm{mM}$ sodium arsenite. Some studies reported that microbial metal removal can be found in exponential, mid exponential and stationary phases of growth (Wang et al.,1997; Yilmaz, 2003).

\section{Biochemical characterization of the bacterial isolate}

\section{i) Gram staining reaction}

Gram staining reaction were performed using crystal violate. Microscopic results showed that some of the isolates retained the violet color while other did not. Among the 13 isolates, 5 (BTL0011, BTL0012, BTL0013, BTL0014 and BTL0016) were gram positive and rests 8 were gram negative.

\section{ii) Potassium hydroxide solubility test}

The gram negative isolate was also confirmed by potassium hydroxide solubility test. The result revealed that an elastic thread or viscous thread was observed when loop raised from the bacterial solution by toothpick a few centimeters from glass slides in case of all gram negative (BTL0015, BTL0017, BTL0018, BTL0019, BTL0020, BTL0021, BTL0022 and BTL0023) bacterial strains.

\section{iii) Growth of the bacterial isolates at varying $\mathrm{pH}$}

The results of optical density indicate that most of the bacterial isolates prefer slightly acidic conditions for their growth followed by neutral to slightly alkaline conditions (Fig. 2a and 2b). These findings are reasonable because the bacteria were isolated from the arsenic contaminated soil of Chandpur and Faridpur having the soil $\mathrm{pH}$ ranges of 5.79 to 8.01 .

Six strains (BTL0014, BTL0016, BTL0019, BTL0020, BTL0022 and BTL0023) showed highest growth at pH 5.5, whereas four (BTL0015, BTL0017, BTL0018, BTL0021), two (BTL0012, BTL0013) and one (BTL0011) showed their highest growth at $6.5,7.5$ and 8.5 , respectively.

\section{Effect of arsenic resistant bacterial inoculation on germination and seedling growth of rice varieties}

Germination and seedling growth of rice were significantly influenced by bacterial inoculum treatments in different levels of arsenic concentration at agar medium. Results showed that highest germination percentage and seedling growth were observed in bacterial inoculation and As treatment combination compared to without bacterial strain and As treatment combination. In $60 \mathrm{ppm}$ of arsenic agar medium, the highest germination percentage and plant height were observed in bacterial strain BTL0022 treatment compared to without bacterial strain where no seed was germinated (Fig. 3 and 4). This was may be due the transformation of inorganic arsenic to less toxic/organic form by bacteria (Singh et al., 2015). The results also revealed that bacterial strain BTL0022 displayed the highest effects on germination and plant height of rice compared to strain BTL0011at different arsenic concentration levels and increasing level of As toxicity decreased the germination of rice varieties (Fig. 3 and 4). It is also revealed that BRRI dhan47 showed tolerance than BRRI dhan29. The results of the present study clearly showed that more germination and seedling growth advantages of rice seed could be achieved by bacterial inoculation under arsenic toxicity condition. 

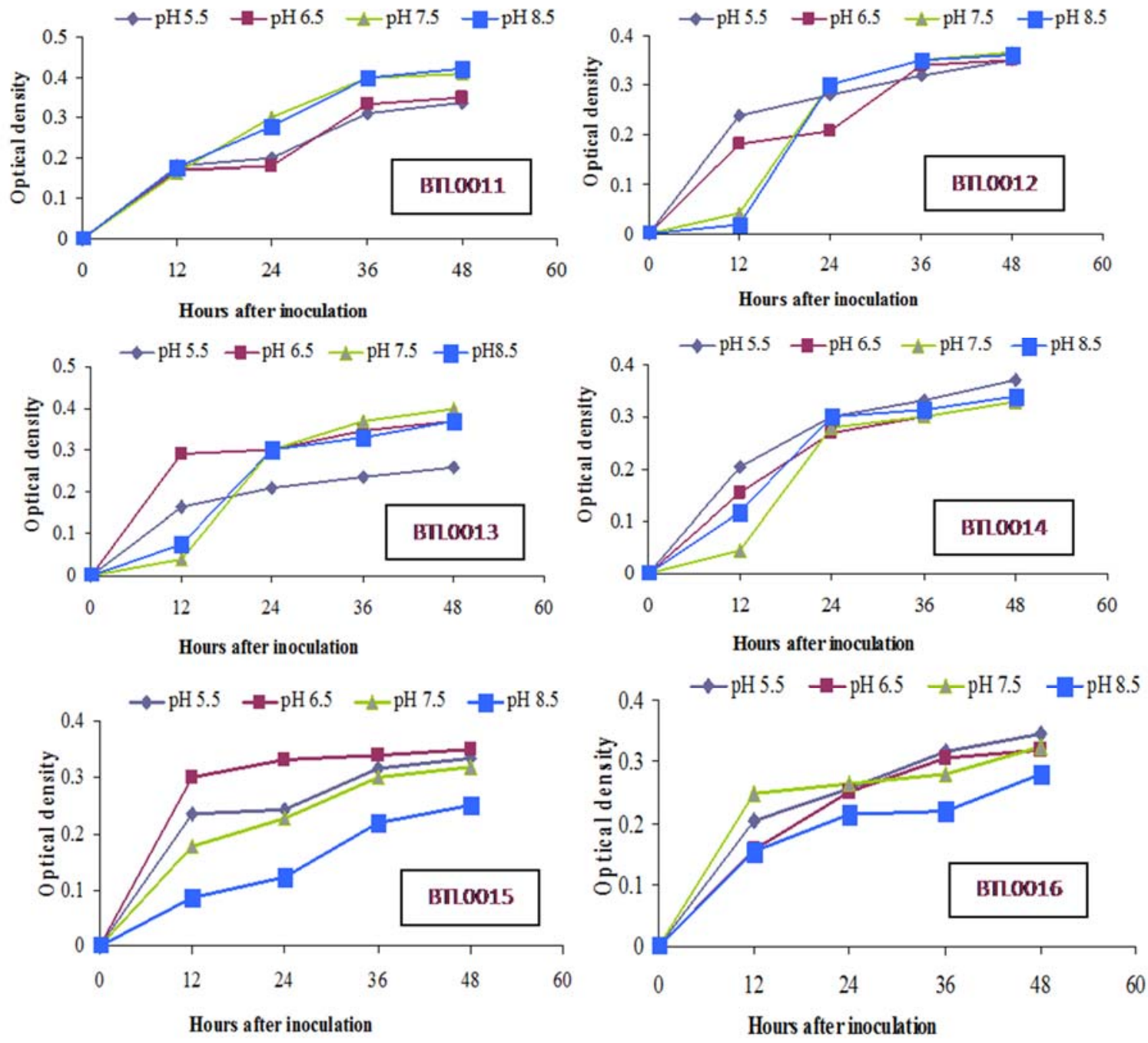

Figure 2(a). Changes of growth of bacterial strains (BTL0011 BTL0016) represented by the optical density at varying $\mathrm{pH}$ 

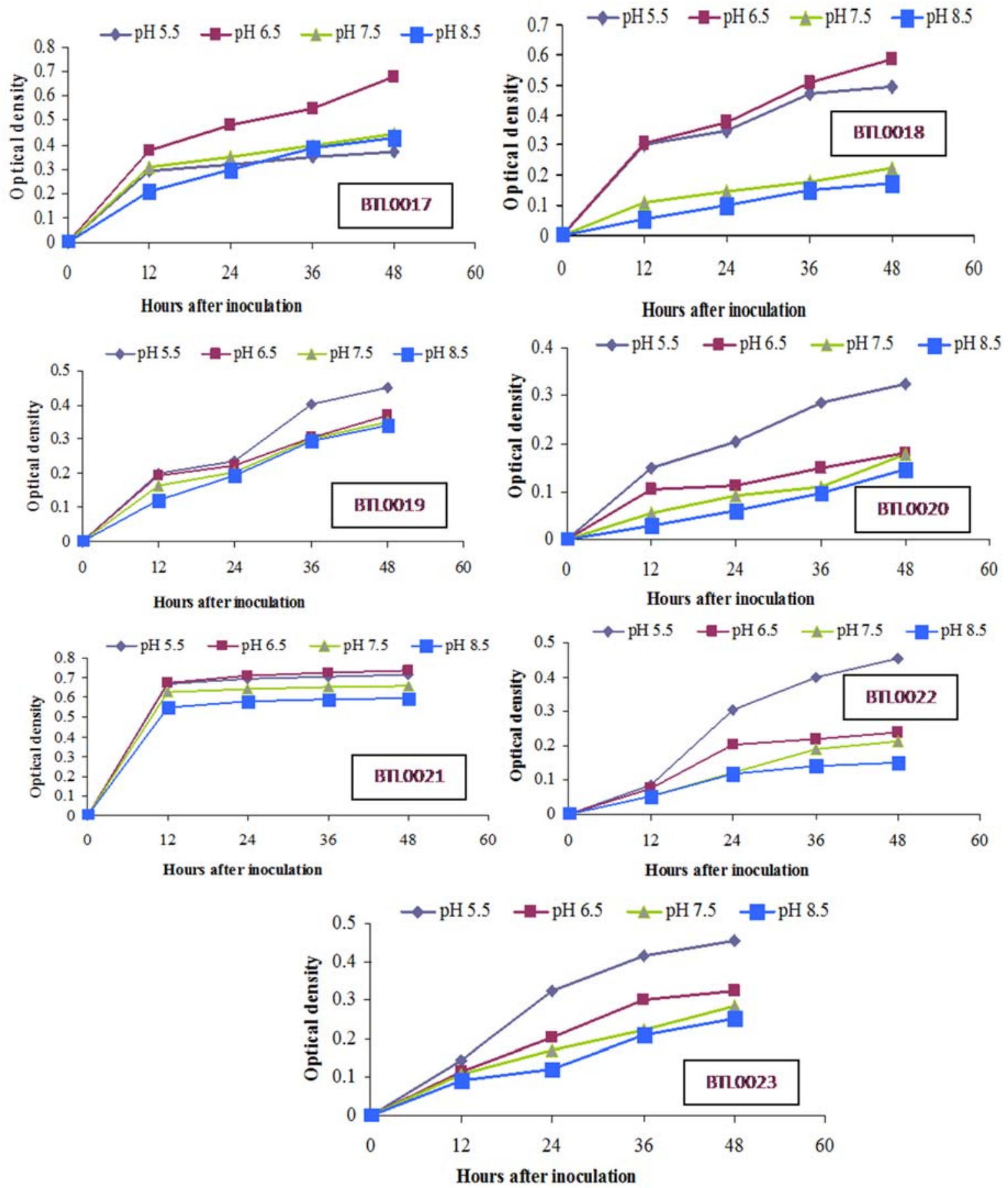

Figure 2(b). Changes of growth of bacterial strains (BTL0017 BTL0023) represented by the optical density at varying $\mathrm{pH}$. 


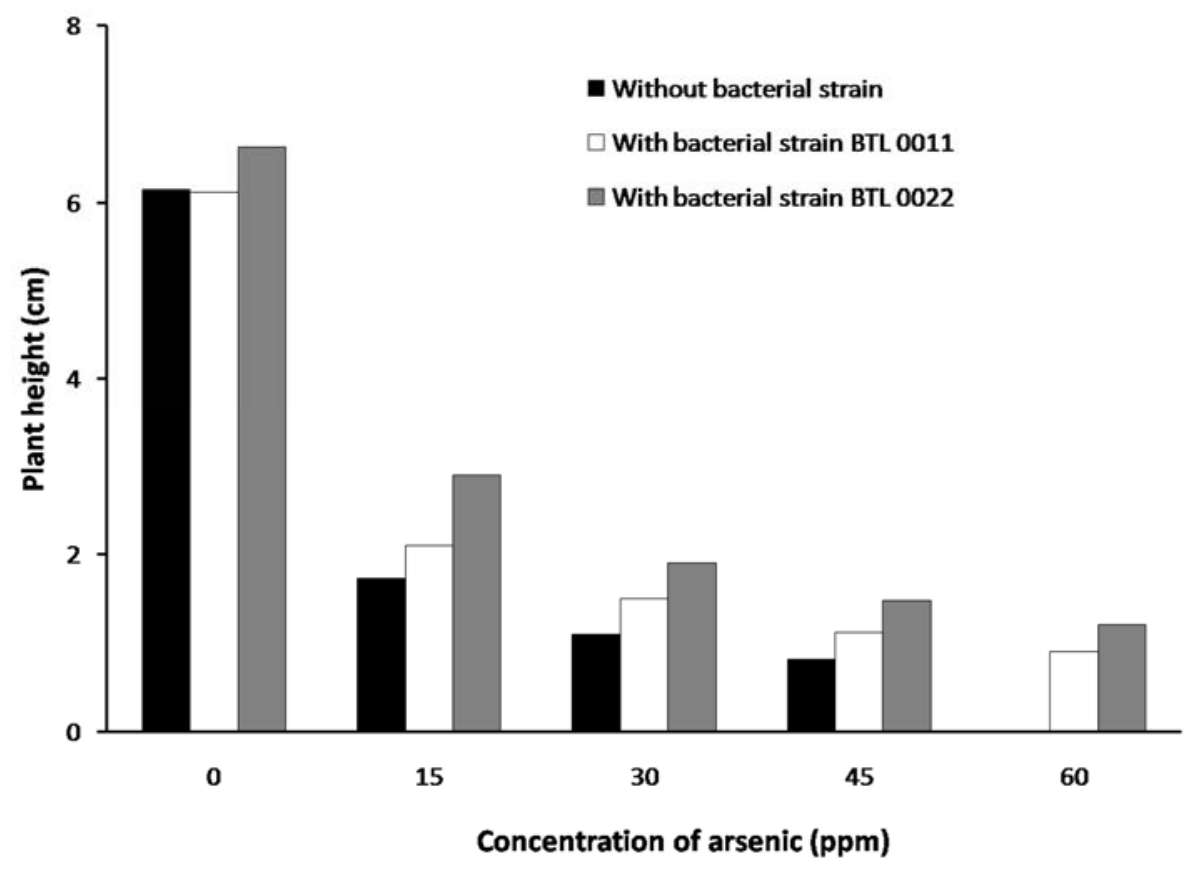

Figure 3. Effect of bacterial strains on plant height of BRRI dhan29

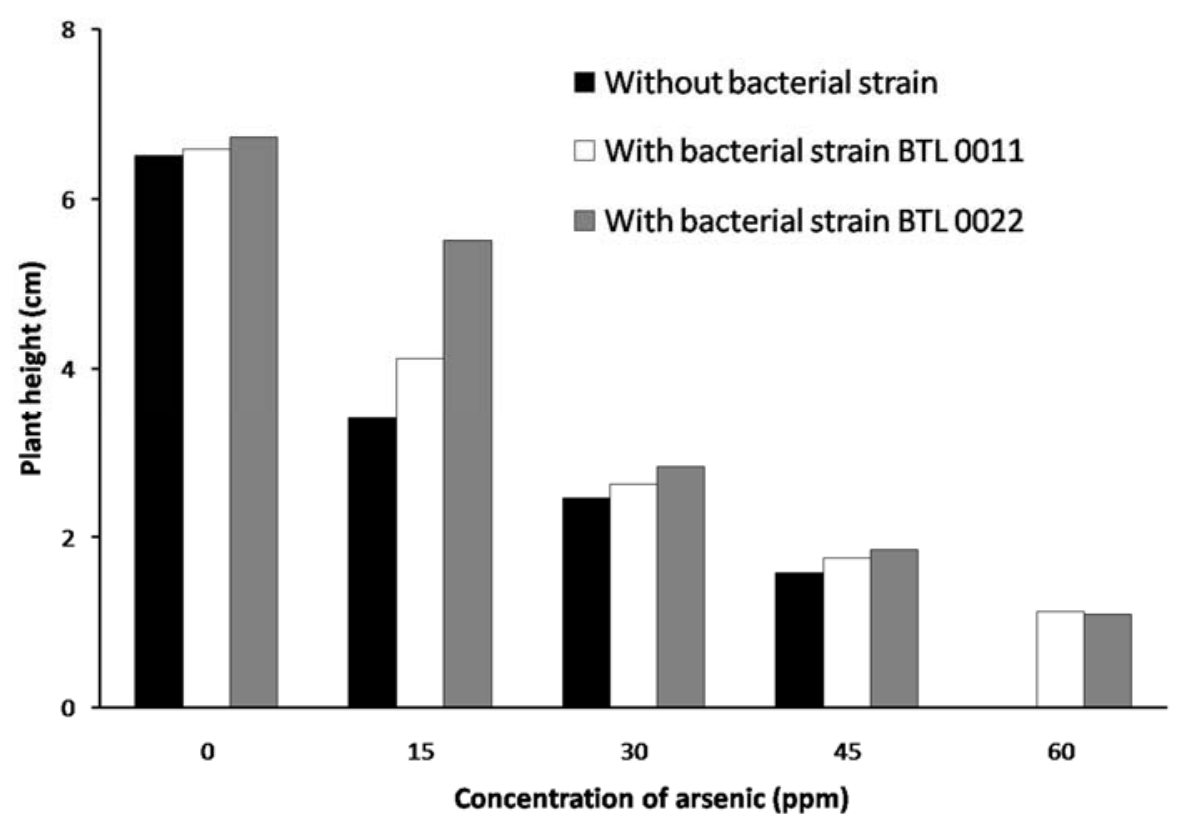

Figure 4. Effect of bacterial strains on plant height of BRRI dhan47 


\section{CONCLUSION}

Thirteen bacterial strains were isolated, characterized and examined their effects on germination and seedling growth of rice. The results of the present study also showed that bacterial strain BTL0022 displayed the highest effects on germination and seedling growth of rice compared to strain BTL0011. The study suggests that those bacteria can be used to increase the germination and seedling growth of rice in As contaminated soils of Bangladesh. Further studies may be undertaken to explore the possibility of isolation of more effective As resistant bacterial strains for rice cultivation as well as for other crops and cropping system to minimize the As toxicity on crops in the country. Advanced molecular studies are needed to identify bacterial isolates through 16s rRNA gene sequencing and also to elucidate the arsenic resistant mechanisms of isolated strains.

\section{COMPETING INTEREST}

The authors declare that they have no competing interests.

\section{ACKNOWLEDGEMENTS}

The corresponding author thankfully acknowledges the Ministry of National Science Information and Communication Technology, Bangladesh for providing financial support in the form of NSICT fellowship.

\section{REFERENCES}

1. Chen M, Ma LQ and Harris WG, 2002. Arsenic concentrations in Florida surface soils: Influence of soil type and properties. Soil Science Society of America, 66: 632-640.

2. Holt JG, Krieg RN, Sneath AHP, Staley TJ and Williams TS, 1994. Burgey's mannual of systematic bacteriology, 9 ed

3. Katsoyiannis I, Zouboulis A, Althoff $\mathrm{H}$ and Bartel $\mathrm{H}, 2002$. As (III) removal from groundwaters using fixedbed upflow bioreactors. Chemosphere, 47: 325-332.

4. Kuai L, Nair AA and Polz MF, 2001. Rapid and simple method for the most-probable-number estimation of arsenic-reducing bacteria. Applied and Environmental Microbiology, 67: 3168-3173.

5. Malik A, 2004. Metal bioremediation through growing cell. Environment International, 30, 261-278.

6. Mandal BK and Suzuki KT, 2002. Arsenic round the world: a review. Talanta, 58: 201-235.

7. Singh S, Shrivastava A, BARLA A and Bose S, 2015. Isolation of arsenic-resistant bacteria from bengal delta sediments and their efficacy in arsenic removal from soil in association with Pteris vittata. Geomicrobiology Journal, 0: 1-12.

8. Srinath T, Verma T, Ramteke PW and Garg SK, 2002. Chromium (VI) biosorption and bioaccumulation by chromate resistant bacteria. Chemosphere, 48: 427-435.

9. Turpeinen R, Pantsar-Kallio M, Haggblom M and Kairesalo T, 1999. Influence of microbes on the mobilization, toxicity and biomethylation of arsenic in soil. Science of the Total Environment, 236: 173-80.

10. Wang CL, Michels PC, Dawson SC, Kitisakkul S, Baross JA, Keasling JD and Clark DS, 1997. Cadmium removal by a new strain of Pseudomonas aeruginosa in aerobic culture. Applied and Environmental Microbiology, 63: 4075-4078.

11. Yamamura S, Ike M and Fujita M, 2003. Dissimilatory arsenate reduction by a facultative anaerobe, Bacillus sp. Strain SF-1. Bioscience and Bioengineering, 96: 454-460.

12. Yilmaz El, 2003. Metal tolerance and biosorption capacity of Bacillus circulans strain EB 1. Research in Microbiology, 154: 409-415.

13. Zouboulis AI, Loukidon MX and Matis KA, 2004. Biosorption of toxic metals from aqueous solutions by bacteria strains isolated from metal-polluted soils. Process Biochemistry, 39: 1-8. 